\title{
A very limited role of tropospheric chlorine as a sink of the greenhouse gas methane
}

\author{
Sergey Gromov ${ }^{1,3}$, Carl A. M. Brenninkmeijer ${ }^{1}$, and Patrick Jöckel ${ }^{2}$ \\ ${ }^{1}$ Max Planck Institute for Chemistry, Atmospheric Chemistry Department, Mainz, Germany \\ ${ }^{2}$ Deutsches Zentrum für Luft- und Raumfahrt (DLR), Institut für Physik der Atmosphäre, \\ Oberpfaffenhofen, Weßling, Germany \\ ${ }^{3}$ Institute of Global Climate and Ecology Roshydromet \& RAS (IGCE), Moscow, Russia
}

Correspondence: Sergey Gromov (sergey.gromov@mpic.de)

Received: 19 February 2018 - Discussion started: 21 February 2018

Revised: 8 June 2018 - Accepted: 23 June 2018 - Published: 12 July 2018

\begin{abstract}
Unexpectedly large seasonal phase differences between $\mathrm{CH}_{4}$ concentration and its ${ }^{13} \mathrm{C} /{ }^{12} \mathrm{C}$ isotopic ratio and their inter-annual variations observed in southern hemispheric time series have been attributed to the $\mathrm{Cl}+\mathrm{CH}_{4}$ reaction, in which ${ }^{13} \mathrm{CH}_{4}$ is discriminated strongly compared to $\mathrm{OH}+\mathrm{CH}_{4}$, and have provided the only (indirect) evidence of a hemispheric-scale presence of oxidative cycle-relevant quantities of tropospheric atomic $\mathrm{Cl}$. Our analysis of concurrent New Zealand and Antarctic time series of $\mathrm{CH}_{4}$ and $\mathrm{CO}$ mixing and isotope ratios shows that a corresponding ${ }^{13} \mathrm{C} /{ }^{12} \mathrm{C}$ variability is absent in $\mathrm{CO}$. Using the AC-GCM EMAC model and isotopic mass balancing for comparing the periods of presumably high and low $\mathrm{Cl}$, it is shown that variations in extra-tropical Southern Hemisphere $\mathrm{Cl}$ cannot have exceeded $0.9 \times 10^{3}$ atoms $\mathrm{cm}^{-3}$. It is demonstrated that the ${ }^{13} \mathrm{C} /{ }^{12} \mathrm{C}$ ratio of $\mathrm{CO}$ is a sensitive indicator for the isotopic composition of reacted $\mathrm{CH}_{4}$ and therefore for its sources. Despite ambiguities about the yield of $\mathrm{CO}$ from $\mathrm{CH}_{4}$ oxidation (with this yield being an important factor in the budget of $\mathrm{CO}$ ) and uncertainties about the isotopic composition of sources of $\mathrm{CO}$ (in particular biomass burning), the contribution of $\mathrm{Cl}$ to the removal of $\mathrm{CH}_{4}$ in the troposphere is probably much lower than currently assumed.
\end{abstract}

\section{Introduction}

Compared to the troposphere's main oxidant $\mathrm{OH}$ (hydroxyl radical), the role of $\mathrm{Cl}$ (atomic chlorine) for $\mathrm{CH}_{4}$ is small. A recently published detailed model-based estimate attributes $\sim 2.6 \%$ of methane's photochemical tropospheric loss to $\mathrm{Cl}$ (Hossaini et al., 2016). Because this loss constitutes only a small term in the methane budget, it might be deemed irrelevant. Nevertheless, growing spatial and temporal coverage in $\mathrm{CH}_{4}$ observational data allows for top-down estimates of changes in the source-sink budget to the order of $\sim 1 \%$. Moreover, considering that the photochemical sink is the dominant and best-known term in the global methane budget, it makes sense to improve our calculations. The grateful aspect of this endeavour clearly is that one does not need an accurate estimate of $\mathrm{Cl}$ as a global tropospheric sink of $\mathrm{CH}_{4}$ as such. It would already be helpful to have independent estimates of the upper limit for this interesting sink of $\mathrm{CH}_{4}$, whose rise in the Anthropocene thus far has contributed onefifth to global warming.

Irrespective of the implications for the $\mathrm{CH}_{4}$ budget, it stands to reason to fully understand tropospheric $\mathrm{Cl}$ and its chemistry in different air masses, from marine boundary layer air to strongly polluted air masses, and several studies address these complex processes. It is also clear that the budget of a species as fickle as atomic chlorine is hard to determine in general terms (which forms a less grateful aspect of "assessing chlorine"). Nevertheless, a new effort - in assessing chlorine's role on a larger than regional scale, on the basis of trace gas measurements, may be useful.

Even more so than for $\mathrm{OH}$, estimates of the abundance of $\mathrm{Cl}$ atoms are chiefly based on indirect evidence. Direct measurements of $\mathrm{OH}$ concentrations $([\mathrm{OH}])$ are difficult and rare, and for $[\mathrm{Cl}]$ this is even much more so. Therefore, the method (by choice or opportunity) is indirect. Not only are 
indirect measurements easier, the use of trace gases that react with $\mathrm{OH}$ and $\mathrm{Cl}$ also has the advantage that space- and timeaveraged estimates are obtainable. In this case, one can select for instance two hydrocarbons, one of which has a comparatively high reactivity to $\mathrm{Cl}$. The change in ratio between the two hydrocarbon concentrations gives information on $[\mathrm{Cl}]$ relative to $[\mathrm{OH}]$.

Using stable isotope ratio information offers another such indirect method. The intrinsic advantage here is that one can use a single trace gas, a single hydrocarbon, or even the much studied greenhouse gas $\mathrm{CH}_{4}$ itself. Although the rate coefficient for the reaction of $\mathrm{OH}$ with ${ }^{12} \mathrm{CH}_{4}$ is only $\sim 4 \%$ o faster than that with ${ }^{13} \mathrm{CH}_{4}$ (Saueressig et al., 2001), for $\mathrm{Cl}+\mathrm{CH}_{4}$ the difference is much larger (Saueressig et al., 1995; Crowley et al., 1999), viz. 63-75\%o (at the range of tropospheric temperatures). Broadly speaking, the presence of ${ }^{13} \mathrm{C}$-enriched $\mathrm{CH}_{4}$ points to reaction with $\mathrm{Cl}$. If this were not enough, one could measure the $\mathrm{D} / \mathrm{H}$ ratio of $\mathrm{CH}_{4}$ and obtain additional valuable information because of the large isotope fractionation (KIE, kinetic isotope effect, formerly and still expressed using the kinetic fractionation constant $\varepsilon=\alpha-1)$ and the differences between the KIEs for ${ }^{13} \mathrm{C}$ and D. A recent paper (Whitehill et al., 2017) reports changes in the clumped isotopic composition of $\mathrm{CH}_{4}$ in reaction with $\mathrm{Cl}$ based on laboratory experiments, raising hope that clumped isotope measurements (which are very difficult) may in an additional way assist to further assess the role of $\mathrm{Cl}$ in the oxidation of $\mathrm{CH}_{4}$ in the atmosphere.

An advantage is that the "stable isotope method" in principle removes the uncertainty about the variability induced by having to use two different trace gas species, each of which may have an independent, variable source. Routinely overlooked is another (principle) advantage of stable isotope analysis offered in the case of atmospheric $\mathrm{CH}_{4} \rightarrow \mathrm{CO}$ conversion, namely measurement of the isotopic composition of the reaction product $\mathrm{CO}$. Even though variations in $[\mathrm{CO}]$ may not be resolvable due to the large spatio-temporal variability of its sources and sink, its ${ }^{13} \mathrm{C} /{ }^{12} \mathrm{C}$ ratio may well tell a clearer story. This is the added advantage of the stable isotope method (we note that the lifetime of ${ }^{14} \mathrm{C}$ is sufficiently long to render much of what is stated to also apply to this wellknown radioisotope, but there are complications on which we cannot dwell here).

In this way the presence of $\mathrm{Cl}$ during Antarctic ozone hole conditions could be inferred in an independent fashion (Brenninkmeijer et al., 1996). Not only did the $\mathrm{CH}_{4}$ inventory become slightly enriched in ${ }^{13} \mathrm{C}$ due to the large KIE in $\mathrm{Cl}+\mathrm{CH}_{4}$, the $\mathrm{CO}$ ensuing from $\mathrm{CH}_{4}$ resulted in strong depletions in the background ${ }^{13} \mathrm{CO}$. There are at least three reasons for the strong isotope depletion. First, $\mathrm{CO}$ concentrations are low in the stratosphere and the in situ produced $\mathrm{CO}$ had a large impact. Second, the ${ }^{13} \mathrm{C}$ content of $\mathrm{CH}_{4}$ is characteristically low due to its chiefly bacterial origin. Third, and this is an important point mentioned above, the ${ }^{13} \mathrm{C} \mathrm{KIE}$ for $\mathrm{Cl}+\mathrm{CH}_{4}$ happens to be very large. The combination of these effects renders the stable isotope analysis of $\mathrm{CO}$ a sensitive indicator. Dealing with tropospheric $\mathrm{Cl}$, the same principle has been applied during springtime tropospheric ozone depletion events in the Arctic. Short-term bursts of free $\mathrm{Cl}$ could be inferred from concomitant decreases in $\delta^{13} \mathrm{C}(\mathrm{CO})$ within a per mil ${ }^{1}$ range (Röckmann et al., 1999).

We record that there also is a removal of $\mathrm{CO}$ by reaction with $\mathrm{Cl}$ atoms, with the rate constant typically being 6 times smaller than that of $\mathrm{CO}+\mathrm{OH}$. Given this very low rate coefficient and the low $\mathrm{Cl} / \mathrm{OH}$ ratio, only an extremely large KIE in the $\mathrm{CO}+\mathrm{Cl}$ reaction could impact significantly on $\delta^{13} \mathrm{C}$ of the $\mathrm{CO}$ inventory. In contrast, the rate constant for $\mathrm{CH}_{4}+\mathrm{Cl}$ is typically 20 times larger than that for $\mathrm{CH}_{4}+\mathrm{OH}$. $\mathrm{Cl}$ is not expected to play a significant role in atmospheric $\mathrm{CO}$ removal, except possibly at polar sunrise (Hewitt et al., 1996) and in some stratospheric chemistry analyses (see, for example, Müller et al., 1996; Sander et al., 2011b). None of a few of papers on tropospheric $\mathrm{CO}$ thus mentions $\mathrm{Cl}$ as a sink for $\mathrm{CO}$ because of its negligible share; fortunately, because the reaction product is not so nice.

In this brief account we cannot do justice to all tropospheric Cl-related papers in the literature and we refer to the recent model-based paper by Hossaini et al. (2016) and references therein. In comparison with $\mathrm{OH}$, which is recycled in about two of three reactions in the troposphere (Lelieveld et al., 2016), the role of recycling of $\mathrm{Cl}$ is lower and not well known. The presence of $\mathrm{Cl}$ in the marine boundary layer has been inferred using hydrocarbon measurements (early study by Parrish et al., 1993) and likewise during polar sunrise (Jobson et al., 1994), $\mathrm{Cl}_{2}$ has been measured in situ in coastal air (Spicer et al., 1998) and in the Arctic (Liao et al., 2014). $\mathrm{ClNO}_{2}$, which is an important precursor, has been measured (Osthoff et al., 2008 and Thornton et al., 2010), also by Young et al. (2012), although they found no $\mathrm{Cl}$ fingerprint in hydrocarbon ratios.

Recently, Baker et al. (2016) inferred the presence of $\mathrm{Cl}$ in pollution outflow from continental Asia using hydrocarbon measurements on air samples collected at cruise altitude by the CARIBIC Lufthansa Airbus aircraft observatory. Before that, Baker et al. (2011) had likewise inferred that $\mathrm{Cl}$ is formed in an emission plume of the Eyjafjallajökull volcano probed by the same CARIBIC A340 aircraft. All these and other publications discuss the presence of $\mathrm{Cl}$ in a variety of tropospheric environments wrestling with the complexity of its chemistry and paucity of experimental data.

The additional importance of revisiting the role of $\mathrm{Cl} \mathrm{rad}$ icals in the present atmosphere actually surfaces in the reconstruction and understanding of the budget of $\mathrm{CH}_{4}$ in the

\footnotetext{
${ }^{1}$ Hereinafter we report the ${ }^{13} \mathrm{C} /{ }^{12} \mathrm{C}$ ratio as per mil delta values. The $\delta^{13} \mathrm{C}$ is defined as $\delta^{13} \mathrm{C}=\left(R / R_{\mathrm{st}}-1\right)$, where $R$ and $R_{\mathrm{St}}$ denote the sample and standard ${ }^{13} \mathrm{C} /{ }^{12} \mathrm{C}$ ratios. We use the VPDB scale with $R_{\mathrm{st}}=11237.2 \times 10^{-6}$ (Craig, 1957) throughout this paper (for details on choosing this value see Gromov et al., 2017, Appendix A).
} 
past. Changes in the tropospheric burden of $\mathrm{CH}_{4}$ that occurred in the past (last glacial maximum to present) are due to changes in $\mathrm{CH}_{4}$ sources and to a minor degree to changes in $\mathrm{OH}$ chemistry (Levine et al., 2011b). One would a priori expect $\delta^{13} \mathrm{C}\left(\mathrm{CH}_{4}\right)$ to provide additional information on source changes, as it did for immediate past changes (Schaefer et al., 2016), were it not the case that large changes in $\mathrm{Cl}$ abundance may well have affected the $\delta^{13} \mathrm{C}\left(\mathrm{CH}_{4}\right)$ record (Levine et al., 2011a). If this is indeed the case, changes in $\mathrm{Cl}$ abundance in the past may have not affected the $\mathrm{CH}_{4}$ budget itself significantly, but may have invalidated to a certain degree the $\delta^{13} \mathrm{C}\left(\mathrm{CH}_{4}\right)$ isotope method for determining changes in sources (biogenic vs. biomass burning).

We turn our attention to a paradox concerning today's tropospheric $\mathrm{Cl}$, namely: if the presence of tropospheric $\mathrm{Cl}$ could be inferred from ${ }^{13} \mathrm{C}$ isotope enrichment in $\mathrm{CH}_{4}$, why is this effect not visible as concurrent isotope depletion in $\mathrm{CO}$ ? Or, more explicitly stated, if the $\delta^{13} \mathrm{C}(\mathrm{CO})$ isotope method for $\mathrm{Cl}$ detection works well for the austral polar stratosphere in spring (Brenninkmeijer et al., 1996) and for the polar sunrise in the Arctic (Röckmann et al., 1999), why not so for the troposphere, or does it? Is a clear negative signal in $\delta^{13} \mathrm{C}(\mathrm{CO})$ indeed absent, and if so, does this absence allow us to cap estimates of tropospheric $\mathrm{Cl}$ levels?

\section{Data analysis}

\subsection{Chlorine in the Southern Hemisphere}

Because the budgets of $\mathrm{CH}_{4}$ and $\mathrm{CO}$ in the Southern Hemisphere ( $\mathrm{SH})$ are less complicated than in the Northern Hemisphere, as is shown by their compact regular seasonal cycles at remote observatories ${ }^{2}$, and because long records of $\mathrm{CO}$ and $\mathrm{CH}_{4}$ including isotopic data are available, we focus on the Southern Hemisphere. In the SH evidently the emphasis is on $\mathrm{Cl}$ generated in the marine boundary layer (MBL).

We first revisit the information on $\mathrm{Cl}$ based on $\delta^{13} \mathrm{C}$ mea-

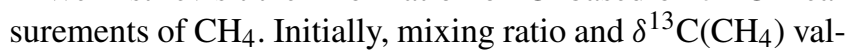
ues for shipboard collected air samples in the Pacific pointed to a large apparent sink isotope fractionation ("apparent" KIE) of $12-15 \%$ - well in excess of the aforementioned $4 \%$ o from $\mathrm{OH}+\mathrm{CH}_{4}$ - which led to the conjecture that a fraction of $\mathrm{CH}_{4}$ is removed in the MBL by $\mathrm{Cl}$ atoms which discriminate strongly against ${ }^{13} \mathrm{CH}_{4}$ (Lowe et al., 1999; Allan et al., 2001). Following several publications exploring this effect, Allan et al. (2007) (hereinafter referred to as A07) using global modelling and observational data from the extratropical Southern Hemisphere (ETSH), confirmed a large apparent KIE and could estimate a global marine boundary layer based $\mathrm{Cl}$ sink for $\mathrm{CH}_{4}$ averaging at $25 \mathrm{Tg}\left(\mathrm{CH}_{4}\right) \mathrm{yr}^{-1}$.

\footnotetext{
${ }^{2}$ see, for example, the synthesis of the $\mathrm{CO}$ and $\mathrm{CH}_{4}$ observational data at https://www.esrl.noaa.gov/gmd/ccgg/gallery/figures/ and references provided therein (last access: 25 November 2017).
}

Given this number, a first-order estimate of the accompanying response of $\delta^{13} \mathrm{C}$ of $\mathrm{CO}$ to the production of $\mathrm{CO}$ from $\mathrm{Cl}+\mathrm{CH}_{4}$ can be made. Assuming a $100 \%$ yield of $\mathrm{CO}$ from $\mathrm{OH}+\mathrm{CH}_{4}$ (and likewise $\mathrm{Cl}+\mathrm{CH}_{4}$ ), the $25 \mathrm{Tg} \mathrm{yr}^{-1}$ $\mathrm{CH}_{4}$ sink corresponds to a $\mathrm{Cl}$-based annual $\mathrm{CO}$ production of $44 \mathrm{Tg} \mathrm{yr}^{-1}$, which is $\sim 1.8 \%$ of the total CO budget. By using a $\delta^{13} \mathrm{C}$ value of $\mathrm{CO}$ of $-28 \%$ (annual tropospheric average), that of $\mathrm{CH}_{4}$ of $-48 \%$ and a $\mathrm{KIE}$ of $70 \%,\left(\mathrm{Cl}+\mathrm{CH}_{4}\right)$ causes a negative shift in $\delta^{13} \mathrm{C}(\mathrm{CO})$ of about $1.6 \%$. Considering that the lifetime of $\mathrm{CO}$ is much shorter than that of $\mathrm{CH}_{4}$ and that $\mathrm{Cl}$ is concentrated in the MBL, the local and/or seasonal effect on $\delta^{13} \mathrm{C}(\mathrm{CO})$ would be even larger.

Unfortunately, a negative shift in $\delta^{13} \mathrm{C}(\mathrm{CO})$ is unwelcome in attempts to close the SH CO budget using $\delta^{13} \mathrm{C}$. As Manning et al. (1997) have pointed out, budget closure is only possible when the yield of $\mathrm{CO}$ from $\mathrm{CH}_{4}+\mathrm{OH}$ (denoted hereinafter as $\lambda$ ) is assumed to be merely about 0.7. In other words, even without incorporating the formation of $\mathrm{CO}$ from $\mathrm{Cl}+\mathrm{CH}_{4}$, the $\mathrm{CH}_{4}$-derived ${ }^{13} \mathrm{C}$-depleted fraction of $\mathrm{CO}$ (which is high in the ETSH at above $40 \%$ ) appeared to be too dominant and had to be reduced by assuming lower yields of $\mathrm{CO}$ from $\mathrm{CH}_{4}$. Soon thereafter, Bergamaschi et al. (2000) also encountered this problem in a 3-D inverse modelling study using the isotopic composition of $\mathrm{CO}$ and could best reconcile data and model by reducing $\lambda$ to about 0.86 . They do mention that incorporating $\mathrm{CO}$ from $\mathrm{Cl}+\mathrm{CH}_{4}$ would require $\lambda$ values as low as 0.71 . Platt et al. (2004), who discuss mechanisms for the production of $\mathrm{Cl}$ in the marine boundary layer, also allude to the necessity to have to reduce the assumed $\mathrm{CO}$ yield of $\mathrm{OH}+\mathrm{CH}_{4}$.

One difficult feature of the $\delta^{13} \mathrm{C}\left(\mathrm{CH}_{4}\right)$-based $\mathrm{Cl}$ estimate was a large inter-annual variability that could not be explained. A07 identified two periods of different $\mathrm{Cl}$ abundance in the ETSH, namely 1994-1996, with MBL values of $28 \times 10^{3}$ atoms cm ${ }^{-3}$ (high-Cl period, "HC") and 19982000 with much lower values, viz. $9 \times 10^{3}$ atoms $\mathrm{cm}^{-3}$ (low$\mathrm{Cl}$ period, "LC"). The nearly 3 -fold drop in the resulting $\mathrm{Cl}+\mathrm{CH}_{4}$ sink rate (37 to $13 \mathrm{Tg}\left(\mathrm{CH}_{4}\right) \mathrm{yr}^{-1}$, or 6.4 to $2.2 \%$ of the total, respectively) inferred from $\delta^{13} \mathrm{C}\left(\mathrm{CH}_{4}\right)$ for the two periods is not discernible in the simultaneous $\delta^{13} \mathrm{C}(\mathrm{CO})$ record (see Sect. 2.2).

Later, Lassey et al. (2011) investigated the apparent KIE in detail and found that it can differ markedly from both the seasonal and mass-balanced KIEs. In other words, the apparent KIE derived from the seasonal changes in $\left[\mathrm{CH}_{4}\right]$ and $\delta^{13} \mathrm{C}\left(\mathrm{CH}_{4}\right)$ values appeared not to properly represent the respective effects of the two KIEs. The implication is that the inferred very large range of $[\mathrm{Cl}]$ may be in error, and the absence of a corresponding signal in $\delta^{13} \mathrm{C}(\mathrm{CO})$ is in that respect an experimental confirmation. Below we will go into detail.

\subsection{Observations in the ETSH}

We scrutinise the mixing and ${ }^{13} \mathrm{C} /{ }^{12} \mathrm{C}$ ratios of $\mathrm{CH}_{4}$ and $\mathrm{CO}$ in the MBL air at Baring Head, New Zealand $\left(41.41^{\circ} \mathrm{S}\right.$, 
$174.87^{\circ} \mathrm{E}, 85 \mathrm{~m}$ a.s.1., denoted hereinafter "BHD") and at Scott Base, Antarctica $\left(77.80^{\circ} \mathrm{S}, 166.67^{\circ} \mathrm{E}, 184 \mathrm{~m}\right.$ a.s.l., denoted "SCB") 3 provided by the National Institute of Water and Atmospheric Research (NIWA, 2010). Examined in the A07 study on $\mathrm{CH}_{4}$, these data are the result of laboratory analyses of large air samples collected on a monthly to weekly basis. The collection strategy (using wind direction, $\mathrm{CO}_{2}$ mixing ratio temporal stability and back-trajectory analysis) allows air masses that represent background ETSH air to be selected. Established over two decades, these time series confer the longest continuous records of ${ }^{13} \mathrm{CH}_{4}$ and ${ }^{13} \mathrm{CO}$ observations to date. The reported overall uncertainties of the $\mathrm{CH}_{4}$ mixing ratio and $\delta^{13} \mathrm{C}$ do not exceed $\pm 0.3 \%$ (about $\pm 5 \mathrm{nmol} \mathrm{mol}^{-1}$ ) and $\pm 0.05 \%$ o (Lowe et al., 1991). For $\mathrm{CO}$, the respective uncertainties are $\pm 4 \% / \pm 0.2 \%$ o (prior to 1994, Brenninkmeijer, 1993) and $\pm 7 \% / \pm 0.8 \%$ o (since 1994, NIWA, 2010). The CO records from BHD and SCB exhibit small variations in annual (minimum-tomaximum) span and no significant long-term trend in both mixing and isotope ratios throughout 1990-2005 (see Gromov, 2013, Sect. 4.1.1). In contrast to this, the concomitant $\left[\mathrm{CH}_{4}\right]$ values have increased on average by about $5 \%$ within the same period, which is consistent with other observational records (Lassey et al., 2010). It can be concluded that such augmentation of atmospheric burden of the major (and largely depleted in ${ }^{13} \mathrm{C}$ ) in situ sources of $\mathrm{CO}$ remains statistically indiscernible in the ETSH $\delta^{13} \mathrm{C}(\mathrm{CO})$ record, because of more perceptible variations caused by changes in sink and/or the other (foremost biomass burning) sources of CO.

We subsequently regard the statistics of the two subsets of observational data falling into the $\mathrm{HC}$ and LC periods, as shown in Fig. 1. For testing the robustness of our comparison against the timing of the air sampling, we "bootstrap" the data by selecting only the pairs of $\mathrm{CH}_{4} / \mathrm{CO}$ samples collected within 1-week windows (shown with solid boxes in Fig. 1). This operation has virtually no effect on $\mathrm{CO}$ distributions, as its statistic is smaller (total of 116 and 88 samples at BHD and SCB, respectively) and controls the sub-sampling of the datasets. For $\mathrm{CH}_{4}$, no effect is noted either, with an exception of significant (i.e. exceeding measurement uncertainty) changes to the "bootstrapped" median $\mathrm{CH}_{4}$ mixing ratio at $\mathrm{BHD}$, which is some $6 \mathrm{nmol} \mathrm{mol}^{-1}$ lower during the $\mathrm{HC}$. This is an indication that the $\mathrm{CO}$ sampling times are likely to be more representative for background air. Overall, we conclude that the $\mathrm{CH}_{4}$ and $\mathrm{CO}$ datasets reflect variations in the composition of the same background air. Contrary to $\mathrm{CH}_{4}$, there is no perceptible reduction in seasonal variations of mixing and isotope ratios of $\mathrm{CO}$ at $\mathrm{SCB}$ throughout the HC period.

\footnotetext{
${ }^{3}$ Sample collection takes place at the designated clean air site Arrival Heights; some of the NIWA datasets use the abbreviation "AHT" for this site.
}

To determine the significance of observed changes in $\mathrm{CO}$ using sufficient statistics, we derive quasi-annual averages (QAAs) of CO mixing / isotope ratio averages representing the HC, LC and long-term periods (all data and from 1994 onwards). For the correct temporal weighting of the samples, we first calculated quasi-monthly averages and their variances, which then contributed equally to the QAA. Table 1 lists the results along with the number of samples used in the calculation. Note that there are about twice as many outliers ${ }^{4}$ in the entire BHD record $(3.8 \%)$ compared to those in the SCB $(2.2 \%)$, which suggests that the estimated difference between the $\mathrm{HC}$ and $\mathrm{LC}$ averages ( $\mathrm{HC}-\mathrm{LC}$, denoted $\Delta$ ) is probably more influenced by regional sources at BHD. Except for $\delta^{13} \mathrm{C}(\mathrm{CO})$ at SCB (with considerable significance of $\Delta$ being negative, $p$ value of 0.79 ), we conclude that all CO QAAs emerge as statistically indistinguishable, also when compared to the long-term averages. For CO mixing ratios, the $\mathrm{Cl}$-driven difference should amount up to $1.2 \mathrm{nmol} \mathrm{mol}^{-1}$ (conservatively assuming up to $50 \%$ of $\mathrm{CO}$ derived from $\mathrm{CH}_{4}$ oxidation changed by $4.2 \%$ ), which is 2.5-3 times smaller than the errors in $\Delta$. At both stations, the $\Delta$ values indicate changes to the atmospheric reservoir involving ${ }^{13} \mathrm{C}$-depleted $\mathrm{CO}$, but in opposite directions (i.e. a removal at $\mathrm{BHD}$ - which contradicts $\mathrm{A} 07$ - and an addition at $\mathrm{SCB}$ ). It is important to note that the $\mathrm{CO}+\mathrm{OH}$ sink alters atmospheric $\mathrm{CO}$ in a similar fashion (i.e. the remaining $\mathrm{CO}$ burden becomes enriched in ${ }^{13} \mathrm{C}$ ).

\subsection{EMAC model}

For extending the interpretation of observed ETSH CO, we resort to the results of simulations performed with the ECHAM5/MESSy Atmospheric Chemistry (EMAC) general circulation model (Jöckel et al., 2010). EMAC includes all relevant processes (atmospheric transport, calculation of chemistry kinetics, photolysis rates, trace gas emissions, etc.) for simulating the current global atmospheric state. The setup we use resembles that of the EMAC evaluation study (MESSy Development Cycle 2, Jöckel et al., 2010) and is augmented with kinetic tagging tools (Gromov et al., 2010). These allow direct quantification of the $\mathrm{CO}$ component stemming from $\mathrm{CH}_{4}$ oxidation (and as corollary provide $\lambda$ ) by following the carbon $(C)$ exchanges through all intermediates (shown in Supplement Fig. S1) within a comprehensive chemistry mechanism simulated by the MECCA submodel (Module Efficiently Calculating the Chemistry of the Atmosphere, Sander et al., 2011a). The emission set-up contains only the standard emissions and precursors of $\mathrm{Cl}$ and yields average $\mathrm{MBL} \mathrm{Cl}$ concentrations in the order of $10^{1}-$ $10^{2}$ atoms $\mathrm{cm}^{-3}$ (see the detailed simulated budgets in the

\footnotetext{
${ }^{4}$ We follow the conventions from Natrella (2003) for identifying statistically significant outliers in the datasets. Samples with mixing ratios falling outside inner and outer statistical fences of \pm 1.5 and \pm 3 interquartile ranges about the median are considered mild and extreme outliers, respectively.
} 
Table 1. Statistics on quasi-annual average (QAA) mixing and isotope ratios of CO observed and simulated at BHD and SCB.

\begin{tabular}{llrrrrrr}
\hline Data & Period & \multicolumn{3}{c}{ BHD } & & \multicolumn{2}{c}{ SCB } \\
\cline { 3 - 8 } & & $n$ & $\mathrm{CO}\left(\mathrm{nmol} \mathrm{mol}^{-1}\right)$ & $\delta^{13} \mathrm{C}(\mathrm{CO})(\% \circ)$ & $n$ & $\mathrm{CO}\left(\mathrm{nmol} \mathrm{mol}^{-1}\right)$ & $\delta^{13} \mathrm{C}(\mathrm{CO})(\% \circ)$ \\
\hline HC & $1994-1996$ & 65 & $56.1 \pm 2.0$ & $-28.97 \pm 0.25$ & 51 & $50.5 \pm 2.6$ & $-29.31 \pm 0.64$ \\
LC $^{\mathrm{a}}$ & $1998-2000$ & 48 & $58.4 \pm 2.1$ & $-29.48 \pm 0.36$ & 35 & $49.7 \pm 2.5$ & $-28.57 \pm 0.64$ \\
\hline \multirow{2}{*}{$\Delta$} & HC-LC & & $-2.2 \pm 2.9$ & $+0.51 \pm 0.43$ & & $+0.8 \pm 3.6$ & $-0.74 \pm 0.90$ \\
& Significance $(p \text { value })^{\mathrm{b}}$ & & $0.12 / 0.002$ & & $0.79 / 0.28$ \\
\hline \multirow{2}{*}{ All data } & $1989-2005$ & $379(15 / 4)$ & $59.2 \pm 1.8$ & $-29.52 \pm 0.29$ & $227(5 / 0)$ & $51.7 \pm 2.1$ & $-29.21 \pm 0.50$ \\
& $1994-2005$ & $192(5 / 1)$ & $57.8 \pm 2.1$ & $-29.38 \pm 0.36$ & $155(0 / 0)$ & $50.8 \pm 2.3$ & $-29.13 \pm 0.58$ \\
\hline EMAC & 1996-2005 & & $57.0 \pm 3.5$ & & & $51.3 \pm 1.7$ & $23.7 \pm 0.3$
\end{tabular}

Notes: Values in parentheses are the number of outliers (mild/extreme; see the footnote 4); the latter were excluded from the calculation of the long-term (up to 2005) averages. Quoted are standard errors of quasi-annual averages $( \pm 1 \sigma){ }^{\text {a }}$ Time-interpolated value is used for February (no samples are available at SCB during the LC period). ${ }^{\mathrm{b}}$ The $p$ value is estimated for the null hypothesis that $\Delta$ of $\delta^{13} \mathrm{C}(\mathrm{CO})$ QAA is below $0 /-2 \sigma$ (left-tail test). ${ }^{\mathrm{c}}$ The aggregate of the emission inventories used in the simulation correspond closest to 2000 (see details in Gromov et al., 2017).

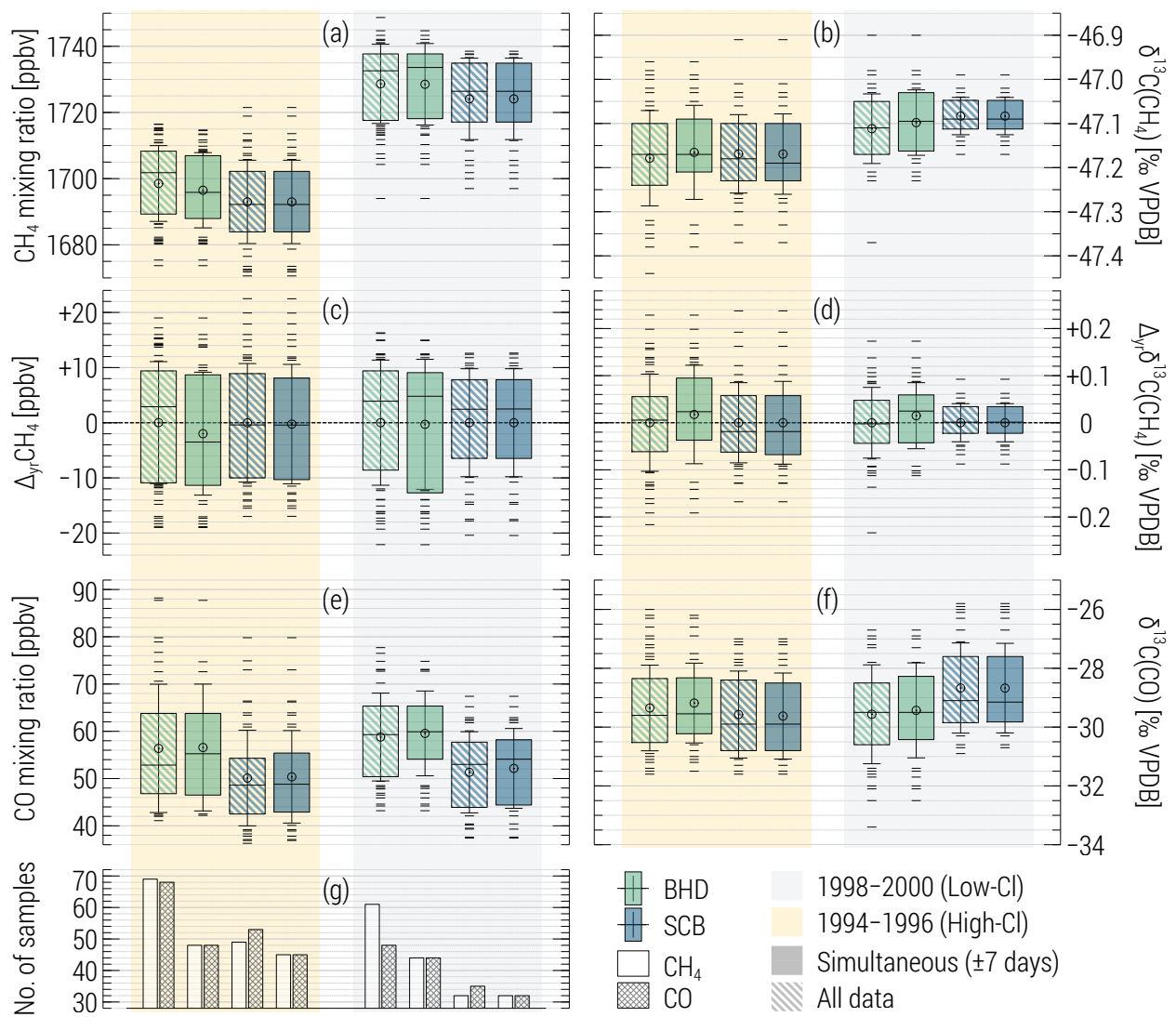

Figure 1. Statistics on the $\mathrm{CH}_{4}$ and $\mathrm{CO}$ mixing and ${ }^{13} \mathrm{C} /{ }^{12} \mathrm{C}$ ratios observed at Baring Head (BHD) and Scott Base (SCB) throughout the high- $\mathrm{Cl}$ (HC, orange shaded) and low-Cl (LC, grey shaded) periods hypothesised by Allan et al. (2007) (see text for details). Panels (c, d) show statistics on the anomalies with respect to the annual averages (denoted with " $\Delta$ yr"). Panel (g) displays the number of samples in each subset. The full time series of the data are shown in the Supplement (Fig. S2). Boxes and whiskers present the median and interquartile ranges and $\pm 1 \sigma$ (of the population) of the data. Circles and minus symbols denote the averages and samples falling outside $\pm 1 \sigma$. Solid boxes denote the subset of data when $\mathrm{CH}_{4}$ and $\mathrm{CO}$ samples were taken simultaneously (up to 7 days apart); hatched boxes refer to all data. 
Supplement, Table S1). These results are in line with MBL [Cl] of $(0.5-2) \times 10^{2}$ atoms $\mathrm{cm}^{-3}$ obtained by Hossaini et al. (2016) in a similar model set-up (ORG2).

The QAAs of [CO] simulated in EMAC for the period 1996-2005 in the grid boxes enclosing the locations of BHD and SCB are also given in Table 1. Despite the spatial and temporal averaging used $\left(\sim 2.8^{\circ}\right.$ horizontal grid cell size at the T42L31ECMWF resolution, weekly averages), model QAAs match observations well and have similar uncertainties (resulting from monthly means variation; the observed and simulated seasonalities are shown in the Supplement, Fig. S3). Due to longer lifetimes of $\mathrm{CO}$ and $\mathrm{CH}_{4}$ in the well-mixed ETSH and, more importantly, their synchronous sink and production via $\mathrm{OH}$, we expect much lower (factor $\sim 1 / 5$ compared to that of the total $\mathrm{CO}$ ) variation in the $\mathrm{CH}_{4}$ derived $[\mathrm{CO}]$ component. The fraction of the latter (denoted $\gamma$, see Table 2) is proportional to the average tropospheric $\lambda$ of $93 \%$ (diagnosed simulated value). Depending on the zonal domain, $\mathrm{Cl}$ atoms in EMAC initiate $(0.15-0.25) \%$ of $\mathrm{CH}_{4}$ sink in the troposphere. The fraction of $\mathrm{CH}_{4}$ removed in the ETSH $\left(43 \mathrm{Tg}(\mathrm{C}) \mathrm{yr}^{-1}\right)$ is minor compared to that in the tropics $\left(271 \mathrm{Tg}(\mathrm{C}) \mathrm{yr}^{-1}\right)$. About $13 \%$ of tropospheric sink occurs in the boundary layer.

Additionally, we simulate the sink-effective ${ }^{13} \mathrm{C}$ enrichment in $\mathrm{CO}$ (denoted $\eta_{\mathrm{c}}$ ) resulting from the ${ }^{12} \mathrm{C}$-preferential $\mathrm{CO}+\mathrm{OH}$ reaction and removal of the $\mathrm{CH}_{4} \rightarrow \mathrm{CO}$ chain intermediates (dry or wet deposition, when $\gamma<1$ ), convoluted with atmospheric mixing and transport. The corresponding $\eta_{\mathrm{c}}$ value at a given space-time point denotes how much higher the $\delta^{13} \mathrm{C}$ of airborne $\mathrm{CO}$ is compared to the case when sink KIEs were absent ${ }^{5}$. Altogether, values of $\gamma$ and $\eta_{\mathrm{c}}$ at the stations and domain-wise integrals of $\mathrm{CH}_{4}$ sink $(S)$ and $\lambda$ (listed in Table 2) are used in the calculations that follow now.

\subsection{Sensitivity of $\delta^{13} \mathrm{C}(\mathrm{CO})$ to the $\mathrm{CH}_{4}+\mathrm{Cl}$ sink}

Using the observational and model data, we attempt to estimate the sensitivity of $\delta^{13} \mathrm{C}(\mathrm{CO})$ at a given station to supposed inter-annual changes in the $\mathrm{Cl}$-initiated $\mathrm{CH}_{4}$ sink. The QAA of $\delta^{13} \mathrm{C}(\mathrm{CO})$ (denoted $\delta_{\mathrm{c}}$ ) can be approximated as a two-component mixture of $\mathrm{CH}_{4}$ - and non- $\mathrm{CH}_{4}$-derived $\mathrm{CO}$ sources augmented by the effective sink enrichment:

$\delta_{\mathrm{c}} \cong(1-\gamma) \delta_{\mathrm{n}}+\gamma\left(\delta_{\mathrm{m}}-\varepsilon_{\mathrm{m}}\right)+\eta_{\mathrm{c}}$.

We refer the reader to Table 2 for the explanation of the parameters and their values. In essence, we account for the fractionations induced in atmospheric sinks ( $\eta_{\mathrm{c}}$ in $\mathrm{CO}$ and $\varepsilon_{\mathrm{m}}$ in $\mathrm{CH}_{4}$ ) and mix the sources in the proportion defined by $\gamma$.

\footnotetext{
${ }^{5}$ This value is obtained in a sensitivity simulation (e.g. without the KIEs in $\mathrm{CO}$ sink and removal of $\mathrm{CH}_{4} \rightarrow \mathrm{CO}$ chain intermediates) and implies linearity (additivity) of atmospheric mixing and transport processes with respect to species $\delta^{13} \mathrm{C}$ (see details in Gromov, 2013, Sects. 6.2.4-5).
}

Table 2. Parameters used in calculus.

\begin{tabular}{|c|c|c|c|}
\hline \multicolumn{2}{|c|}{ Species and parameter (unit) } & \multicolumn{2}{|c|}{ Value } \\
\hline \multirow[b]{2}{*}{$\mathrm{CO}$} & & \multicolumn{2}{|c|}{ Station } \\
\hline & & BHD & SCB \\
\hline$\gamma^{\mathrm{a}}$ & $\mathrm{CH}_{4}$-derived component $(\%)$ & $43 \pm 3$ & $46 \pm 2$ \\
\hline$\eta_{\mathrm{c}}^{\mathrm{a}}$ & Eff. ${ }^{13} \mathrm{C}$ sink fractionation $(\% o)$ & $+4.2 \pm 0.2$ & $+4.6 \pm 0.1$ \\
\hline$\delta_{\mathrm{n}}^{\mathrm{b}}$ & $\delta^{13} \mathrm{C}$ of non- $\mathrm{CH}_{4}$ sources $(\% o)$ & $-15.0 \pm 1.7$ & $-12.8 \pm 1.3$ \\
\hline \multirow[t]{2}{*}{$\delta_{\mathrm{c}}$} & Observed $\delta^{13} \mathrm{C}(\mathrm{CO})(\% o)$ & $-29.5 \pm 0.3$ & $-29.2 \pm 0.5$ \\
\hline & & \multicolumn{2}{|c|}{ Domain: } \\
\hline \multicolumn{2}{|l|}{$\mathrm{CH}_{4}$} & SH & ETSH \\
\hline$S^{\mathrm{a}, \mathrm{c}}$ & Total sink $\left(\operatorname{Tg}(C) \mathrm{yr}^{-1}\right)$ & 187.8 & 52.5 \\
\hline$\delta_{\mathrm{m}}$ & Observed $\delta^{13} \mathrm{C}\left(\mathrm{CH}_{4}\right)(\% \circ)$ & \multirow{2}{*}{\multicolumn{2}{|c|}{$\begin{array}{c}-47.2 \\
03 \%\end{array}$}} \\
\hline \multirow[t]{3}{*}{$\lambda^{\mathrm{a}}$} & Yield of $\mathrm{CO}$ from $\mathrm{CH}_{4}$ & & \\
\hline & & \multicolumn{2}{|c|}{ Period $^{\mathrm{d}}$ : } \\
\hline & & $\mathrm{HC}$ & $\mathrm{LC}$ \\
\hline$\Delta S$ & $\begin{array}{l}\text { Changes to } S \text { due to } \mathrm{Cl} \text { variations } \\
\left(\operatorname{Tg}(\mathrm{C}) \mathrm{yr}^{-1}\right)\end{array}$ & +18 & 0 \\
\hline$\varepsilon_{\mathrm{m}}$ & Total $\mathrm{CH}_{4}$ sink KIE $(\% o)$ & 15 & 7 \\
\hline
\end{tabular}

Notes: Quoted QAAs and standard errors $( \pm 1 \sigma)$; the latter are omitted for the components contributing to $\delta_{\mathrm{c}}$ and $\delta_{\mathrm{n}}$ errors insignificantly. ${ }^{\mathrm{a}}$ Estimate based on EMAC results. ${ }^{\mathrm{b}}$ Derived at $\varepsilon_{\mathrm{m}}=11 \%$ (average of the LC and $\mathrm{HC}$ periods). ${ }^{\mathrm{c}}$ Includes the $\mathrm{LC} \mathrm{Cl} \mathrm{sink} \mathrm{term} \mathrm{from} \mathrm{A07}$ $\left(9.7 \mathrm{Tg}(\mathrm{C}) \mathrm{yr}^{-1}\right)$. For the $\mathrm{SH}$, the sum of the ETSH and halved intra-tropical integrals is taken.
d Estimates from A07.

Exemplifying the estimate from $\mathrm{A} 07, \mathrm{SH} \mathrm{Cl}$ changes should cause $\varepsilon_{\mathrm{m}}$ to drop from $15 \%$ to $7 \%$ o between the $\mathrm{HC}$ and LC, rendering $\delta^{13} \mathrm{C}$ of the carbon from $\mathrm{CH}_{4}$ arriving to $\mathrm{CO}$ of $-62.2 \% o$ and $-54.2 \%$, respectively. By rearranging Eq. (1) we derive the non- $\mathrm{CH}_{4} \mathrm{CO}$ source $\delta^{13} \mathrm{C}$ signature $\delta_{\mathrm{n}}$ (see Table 2). Since there are virtually no surface sources of $\mathrm{CO}$ south of $40^{\circ} \mathrm{S}$ in the ETSH (see, for example, Gromov et al., 2017, Sect. 3.4), the difference in $\delta_{\mathrm{n}}$ at BHD and SCB could be driven only by poleward ${ }^{13} \mathrm{C}$ enrichment of the non- $\mathrm{CH}_{4}$ in situ sources (e.g. oxidation of higher hydrocarbons) and/or a stronger (than simulated in EMAC) zonal gradient in $\eta_{\mathrm{c}}$. Note that the station-wise $\delta_{\mathrm{n}}$ discrepancy scales with the $\varepsilon_{\mathrm{m}}$ value, although not strongly: at $\varepsilon_{\mathrm{m}}$ of OH sink KIE (3.9\%o) it reduces from $(2.2 \pm 2.1) \%$ o to $(1.5 \pm 2.2) \%$ o. In a statistical sense, the derived $\delta_{\mathrm{n}}$ values reflect the same underlying source signature ( $p$ value is 0.31 ).

Using Eq. (1) to define $\delta_{\mathrm{c}}$ in the HC and LC periods, one obtains its sensitivity $\left(\Delta \delta_{\mathrm{c}}\right)$ to changes in the $\mathrm{CH}_{4}+\mathrm{Cl}$ sink $(\Delta S)$ and in the total sink $\operatorname{KIE}\left(\Delta \varepsilon_{\mathrm{m}}\right)^{6}$ :

$\Delta \delta_{\mathrm{c}}=\left(\lambda_{\mathrm{a}} / \lambda\right)^{\mathrm{LC}} \gamma\left(\left(\delta_{\mathrm{m}}-{ }^{\mathrm{HC}} \varepsilon_{\mathrm{m}}-\delta_{\mathrm{n}}\right) \mu-\Delta \varepsilon_{\mathrm{m}}\right)$.

Here superscripts indicate the period the values are taken for, $\Delta$ denotes the HC - LC difference (same as in Sect. 2.2 above) and $\mu=\Delta S /{ }^{\mathrm{LC}} S$ is the change in the total $\mathrm{CH}_{4}$ sink $S$ relative to the LC conditions. The value of $S$ represents the tropospheric column of a given domain, i.e. we assume that

\footnotetext{
${ }^{6}$ Explicit derivation of this and following equations is shown in Appendix A.
} 
$\Delta S$ is distributed homogeneously over the SH or ETSH. Formulated using $\gamma$, Eq. (2) allows the projection of the results for the alternative $\mathrm{CO}$ yield value $\lambda_{\mathrm{a}}$ (different from that obtained in EMAC), as our simulations confirm that $\lambda$ directly proportionates $\gamma$ and $S$ in the tropospheric column (but not in the MBL). Furthermore, $\Delta \delta_{\mathrm{c}}$ is derived under the assumption of constancy of $\eta_{\mathrm{c}}$ and $\delta_{\mathrm{n}}$ values. Whilst for $\eta_{\mathrm{c}}$ such is likely the case (judging by the very similar observed $\mathrm{CO}$ mixing ratios, and hence lifetimes, during $\mathrm{HC}$ and LC), for the latter an upper limit of $\pm 1 \%$ can be put from the typical variation in the $\delta^{13} \mathrm{C}$ of the underlying sources (see Gromov et al., 2017, Table 5). This is lower than the uncertainty associated with $\delta_{\mathrm{n}}$ values derived here (cf. Table 2); we discuss the range of $\delta_{\mathrm{n}}$ values required to concomitantly mask the changes in $\delta_{\mathrm{c}}$ below.

Figure 2a shows the values of $\Delta \delta_{\mathrm{c}}$, calculated for different stations and domains, as a function of $\gamma$ (implicitly scaling with arbitrarily chosen yield value $\lambda_{\mathrm{a}}$ ). Very large changes are expected for the ETSH, where $\mu$ is about 4 times that in the SH. Importantly, the ${ }^{\mathrm{LC}} S$ value includes the $\mathrm{Cl}$ sink term from $\mathrm{A} 07$ (which is $\sim 29$ times greater than the total tropospheric $\mathrm{CH}_{4}+\mathrm{Cl}$ sink simulated in EMAC); hence, we receive the "lowest sensitivity" for the case when the $\mathrm{Cl}$ sink is added up to (instead of partly replacing) the other $\mathrm{CH}_{4}$ sinks, e.g. that via $\mathrm{OH}$. Alternatively, $\Delta \delta_{\mathrm{c}}$ will additionally intensify by $-0.2 \%$ and $-(1.8-2.1) \% o$ in the SH and ETSH, respectively. By setting $\mu=0$ in Eq. (2), we quantify the contribution of the $\mathrm{CH}_{4}$ sink KIE (which increases by $\Delta \varepsilon_{\mathrm{m}}$ ) only. Independent from the assumptions on the $\mathrm{Cl}$ sink domain and magnitude, it demonstrates the effect of lowering of $\delta^{13} \mathrm{C}$ of $\mathrm{C}$ arriving to $\mathrm{CO}$ from $\mathrm{CH}_{4}$ and accounts for one-third to two-thirds of the total $\Delta \delta_{\mathrm{c}}$ value (cf. Fig. 2, thin dasheddotted line).

Finally, we estimate the equivalent increase in the $\delta^{13} \mathrm{C}$ value of the non- $\mathrm{CH}_{4}$ sources $\left(\Delta \delta_{\mathrm{n}}\right)$ that would be required to mask the depleting effect of a hypothetical $\mathrm{CH}_{4}+\mathrm{Cl}$ sink increase. We subtract Eq. (1) written for the $\mathrm{HC}$ and LC and solve it assuming $\Delta \delta_{\mathrm{c}}=0$ (notation from Eq. 2 is kept):

$\Delta \delta_{\mathrm{n}}=\frac{\left(\delta_{\mathrm{n}}-\left(\delta_{\mathrm{m}}-{ }^{\mathrm{LC}} \varepsilon_{\mathrm{m}}\right)\right) \mu+(1+\mu) \Delta \varepsilon_{\mathrm{m}}}{\left(\left(\lambda_{\mathrm{a}} / \lambda\right)^{\mathrm{LC}} \gamma\right)^{-1}-(1+\mu)}$.

Averages of $\Delta \delta_{\mathrm{n}}$ at BHD and SCB are plotted in the lower panel of Fig. $2 \mathrm{a}$, respectively. Similar to $\Delta \delta_{\mathrm{c}}, \Delta \delta_{\mathrm{n}}$ scales with the assumed domain and $\mathrm{CH}_{4}$ input to $\mathrm{CO}$, albeit stronger, because $\delta_{\mathrm{n}}$ is closer to the $\delta^{13} \mathrm{C}$ of the total $\mathrm{CO}$ source $\left(\delta_{\mathrm{c}}-\eta_{\mathrm{c}}\right)$ compared to that for $\mathrm{CH}_{4}\left(\delta_{\mathrm{m}}-\varepsilon_{\mathrm{m}}\right)$. Thus, if we accept the EMAC-suggested tropospheric $\mathrm{CO}$ yield in the $\mathrm{SH}$ of $\lambda=93 \%$, Cl-driven changes to the $\delta^{13} \mathrm{C}(\mathrm{CO})$ at BHD and SCB are expected to be of at least -(5.8-6.3)\%o between the $\mathrm{LC}$ and $\mathrm{HC}$, unless these are masked by unrealistic concurrent increases in $\delta^{13} \mathrm{C}$ of the non- $\mathrm{CH}_{4}$ sources of about $+(11.6-13.5) \%$. If one assumes the $\mathrm{CH}_{4}+\mathrm{Cl}$ sink changes only within the ETSH, these estimates scale to -(13.1$14.5) \% o$ and $+(46-61) \%$, respectively. It is important to

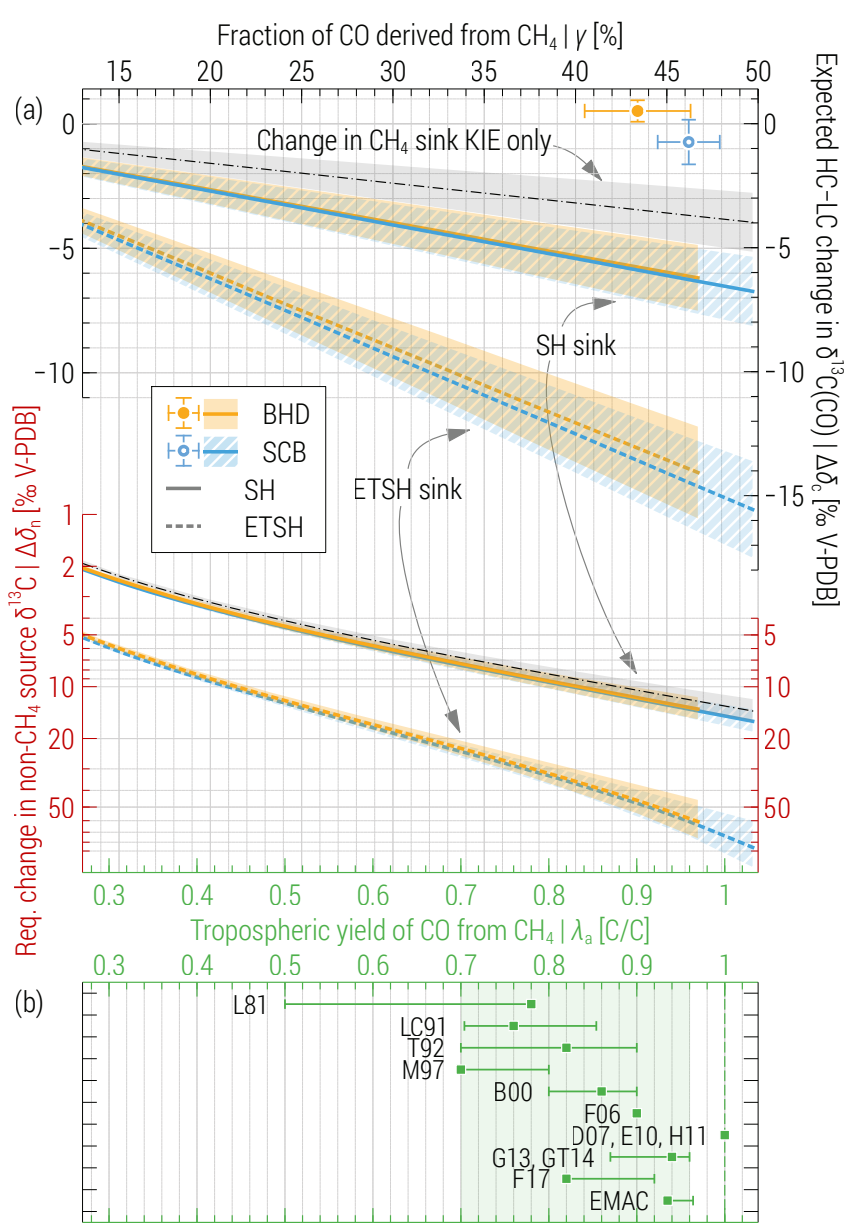

Figure 2. (a) Top: expected $\mathrm{CH}_{4}+\mathrm{Cl}$ sink-driven changes to $\delta^{13} \mathrm{C}(\mathrm{CO})$ between $\mathrm{HC}$ and LC periods at the ETSH stations $\left(\Delta \delta_{\mathrm{c}}\right)$ as a function of $\mathrm{CH}_{4}$-derived $\mathrm{CO}$ fraction ( $\gamma$, top axis) resulting from assumed yield values ( $\lambda_{\mathrm{a}}$, bottom axis, approximate). Large symbols denote the observed (ordinate) and simulated (abscissa, EMAC) values. Thick lines present $\Delta \delta_{\mathrm{c}}$ values calculated using Eq. (2) assuming that hypothesised changes to the $\mathrm{CH}_{4}+\mathrm{Cl}$ sink occur within the entire SH (solid) and ETSH only (dashed). Thin dashed-dotted lines exemplify the effect due to mere changes in $\mathrm{CH}_{4}$ sink $\mathrm{KIE}\left(\Delta \varepsilon_{\mathrm{m}}\right)$. Bottom: average augmentation to the non$\mathrm{CH}_{4}$ sources signature $\left(\Delta \delta_{\mathrm{n}}\right)$ required to compensate $\Delta \delta_{\mathrm{c}}$ at the respective values and domains (note the different axis shown in red). Errors bars and areas denote $\pm 1 \sigma$ of the annual means and derived estimates. See Sects. 2.4 and 3 for details. (b) Tropospheric yield of $\mathrm{CO}$ from $\mathrm{CH}_{4}$ oxidation reckoned in the current and previous studies. Symbols (error bars) denote the best (range of) estimates or the global (domain) averages. Abbreviations refer to the following: L81 - Logan et al. (1981), LC91 - Lelieveld and Crutzen (1991), T92 - Tie et al. (1992), M97 - Manning et al. (1997), B00 - Bergamaschi et al. (2000), F06 - Folberth et al. (2006), D07 - Duncan et al. (2007), E10 - Emmons et al. (2010), H11 - Hooghiemstra et al. (2011), G13 - Gromov (2013), GT14 - Gromov and Taraborrelli, MPI-C (unpublished results using EMAC, 2014), F17 - Franco et al. (2018), EMAC - current study. 
note that we gauge the expected changes to the annual averages of $\delta^{13} \mathrm{C}(\mathrm{CO})$, which do integrate seasonal variations. The latter are observed at merely $\pm 1.5 \%$ (cf. Figs. 1 and S2) and should also increase strongly, if the $\mathrm{Cl}$ sink has a similar seasonal variation to that of $\mathrm{OH}$ (although $\mathrm{A} 07$ used a seasonal cycle based on dimethyl-sulfide-related species in the $\mathrm{SH}$, which has a shorter summer maximum).

\section{Discussion}

The photochemical yield of $\mathrm{CO}$ from $\mathrm{CH}_{4}$ constitutes a major factor of uncertainty in the CO budget. Modelling studies to date agreed on values of $\lambda \geq 0.7$ (see the overview in Fig. 2b). Several recent studies (see D07, E10 and H11) suggest, however, that $\lambda$ is close to unity and by doing so contradict findings of ${ }^{13} \mathrm{CO}$-inclusive studies (see M97, B00 and G13). Assuming that $\lambda<0.7$ or that $\lambda \sim 1$ would be in conflict with basic principles, i.e. photochemical kinetics and dry and wet removal processes affecting the intermediates of the $\mathrm{CH}_{4} \rightarrow \mathrm{CO}$ chain, or their erroneous implementation in the global atmospheric models.

Our estimates of $\Delta \delta_{\mathrm{c}}$ bear the uncertainty of the assumed $\lambda$ value; nonetheless, they affirm that even if only $70 \%$ of reacted $\mathrm{CH}_{4}$ molecules yield $\mathrm{CO}$, at least one-third of the changes to the $\delta^{13} \mathrm{C}$ signature of this source (that is, $\left(\delta_{\mathrm{m}}+\varepsilon_{\mathrm{m}}\right)$ times 0.7) should be expressed in the ETSH $\delta^{13} \mathrm{C}(\mathrm{CO})$. Since $\delta_{\mathrm{m}}$ changed by about $+0.1 \%$ o between the $\mathrm{HC}$ and LC periods (cf. Fig. 1b), we conclude that $\varepsilon_{\mathrm{m}}$ could not change by more than $+2 \%$ in the $\mathrm{SH}$ as well (with this estimate being lower for $\lambda$ above 0.7$)^{7}$. Furthermore, statistically significant non-zero $\Delta \delta_{\mathrm{c}}$ values ( $p$ value of 0.01 ) should appear at very low $\lambda$, viz. above 0.05 (ETSH sink) and 0.12 (SH sink, respectively). We regard these two atmospheric domains because observations in the well-mixed ETSH may not single out the actual location of the $\mathrm{Cl}+\mathrm{CH}_{4}$ sink: The large part of sink-driven variations in the mixing ratio and $\delta^{13} \mathrm{C}$ of $\mathrm{CH}_{4}$ and $\mathrm{CO}$ is merely transported into the ETSH from the tropics, where almost three-quarters of the total $\mathrm{CH}_{4}$ sink and accompanying $\mathrm{CO}$ production is expected (see Table $\mathrm{S} 1$ for EMAC results, also Gromov, 2013, Sect. 6.2.3). Accordingly, Hossaini et al. (2016) also assign a major fraction of the $\mathrm{CH}_{4}+\mathrm{Cl}$ sink to the lower latitudes. If such were not the case (i.e. if varying $\mathrm{Cl}+\mathrm{CH}_{4}$ sink were confined to the ETSH), the estimated effect on $\delta^{13} \mathrm{C}(\mathrm{CO})$ would be roughly twice that reckoned for the $\mathrm{SH}$, i.e. extreme values.

There are a few remarks on the usability of the method used by A07, in addition to the thorough theoretical enquiry by Lassey et al. (2011). Evidence, or at least indications, for $\mathrm{Cl}$ in the ETSH is based on the $\left[\mathrm{CH}_{4}\right]$ vs. ${ }^{13} \mathrm{C}\left(\mathrm{CH}_{4}\right)$ Lissajous (a.k.a. phase) diagrams being ellipses in the case of seasonal cycles. The slope of their major axis gives the "apparent" KIE, from which the ratio $\mathrm{Cl} / \mathrm{OH}$ can be inferred

\footnotetext{
${ }^{7}$ Calculated as $\left(\Delta \delta^{13} \mathrm{C}(\mathrm{CO})-0.1 \% o\right) /(\gamma \cdot \lambda)$ for values at SCB (see Tables 1 and 2).
}

when the individual KIEs are known. Clearly, $\mathrm{Cl}$ was not assessed on the basis of the annual average value of $\delta^{13} \mathrm{C}\left(\mathrm{CH}_{4}\right)$ but on the basis of its seasonal cycle, which is small. Using annual averages, however, is still impeded by percepti-

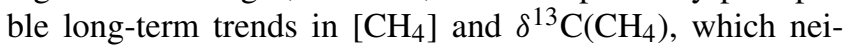
ther A07 (who consider the final 8 equilibrated years of the 40-year spin-up simulations) nor Lassey et al. (2011) (who use a rather idealised model) have accounted for. For example, presence and asynchronous evolution of $\left[\mathrm{CH}_{4}\right]$ and ${ }^{13} \mathrm{C}\left(\mathrm{CH}_{4}\right)$ long-term trends could result in different mixing and transport of $\mathrm{CH}_{4}$ isotopologues compared to that resulting from trend-free simulated seasonal variations. We note that while observed $\left[\mathrm{CH}_{4}\right]$ growth is similar throughout both $\mathrm{HC}$ and LC periods, such is not the case for $\delta^{13} \mathrm{C}\left(\mathrm{CH}_{4}\right)$, which does not increase in the LC (cf. Fig. S2a, c and, in particular, the seasonal time series fits for $\mathrm{CH}_{4}$ at the NIWA website $^{8}$ ). Furthermore, the latter is likely a global signal of the 2000-2007 intermittent stop in tropospheric $\mathrm{CH}_{4}$ growth, which manifested itself in $\delta^{13} \mathrm{C}$ earlier than in mixing ratios and terminated with the reversed ${ }^{13} \mathrm{C} /{ }^{12} \mathrm{C}$ trend (see, for example, Nisbet et al., 2016). Currently available observational data do not allow unambiguous attribution of this global phenomenon to one or several causes proposed (Turner et al., 2017), however.

Our incomplete information about the ${ }^{13} \mathrm{C}$ isotopic composition of $\mathrm{CH}_{4}$ sources presently prevents a $\mathrm{Cl}$-induced input into the annual average value of $\delta^{13} \mathrm{C}\left(\mathrm{CH}_{4}\right)$ being singled out, even though it should be perceptible (about $+1.5 \%$, assuming for the sake of matter a $2.5 \% \mathrm{Cl}$ sink). The corresponding negative shift in $\delta^{13} \mathrm{C}(\mathrm{CO})$ is about $1.6 \%$ (esti-

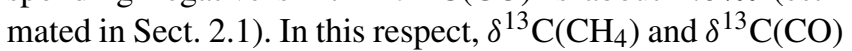
are equally sensitive to $\mathrm{Cl}$. Because oxidation of $\mathrm{CH}_{4}$ is a main source of $\mathrm{CO}$ in the ETSH, and the isotopic composition of atmospheric $\mathrm{CH}_{4}$ is better known than that of its sources, it may well be that variation in the annual average value of $\delta^{13} \mathrm{C}(\mathrm{CO})$ is a more useful variable for estimating $[\mathrm{Cl}]$. The relatively long lifetime and small seasonality in sources result in weak seasonal cycles of mixing ratio and $\delta^{13} \mathrm{C}$ in $\mathrm{CH}_{4}$. In contrast, the seasonal cycle of $\delta^{13} \mathrm{C}(\mathrm{CO})$ is dominated by the large difference in isotopic composition of its sources, with the main driver being the switch between $\mathrm{CO}$ from $\mathrm{CH}_{4}$ oxidation and that of the other sources. Since the presence of $\mathrm{Cl}$ makes $\mathrm{CH}_{4}$ oxidation an even more ${ }^{13} \mathrm{C}$ depleted source, the impact of $\mathrm{CH}_{4}$ oxidation on $\mathrm{CO}$ in the ETSH peaks and may render the seasonal amplitude (in particular summer minima) of $\delta^{13} \mathrm{C}(\mathrm{CO})$ a sensitive indicator for $\mathrm{Cl}$. Unfortunately, deficit of observational data (large uncertainties due to insufficient statistics) currently hinder such application.

A fundamental problem remains that the $\mathrm{ETSH} \delta^{13} \mathrm{C}(\mathrm{CO})$ budget cannot be closed even when a $\mathrm{Cl}$ sink is excluded, unless a $\mathrm{CO}$ yield from $\mathrm{CH}_{4}$ of $0.7-0.86$ is assumed (Manning

\footnotetext{
${ }^{8}$ https://www.niwa.co.nz/atmosphere/our-data/trace-gas-plots/ methane (last access: 17 December 2017).
} 
et al., 1997; Bergamaschi et al., 2000). Yields below unity leave, however, the possibility that a positive fractionation in the removal of the $\mathrm{CH}_{4} \rightarrow \mathrm{CO}$ intermediates may be at play. Using $\lambda=(0.7-0.86)$ and $\gamma=0.3$ for the troposphere, one calculates that an average KIE of (11-33)\%o should escort the removal of intermediates in order to offset the $\mathrm{Cl}$ input to $\delta^{13} \mathrm{C}(\mathrm{CO})$. This estimate is $3-8$ times higher than current parameterisations suggest (about 4\%, see Gromov, 2013, Sect. 6.2.4) and is even higher in the SH, where $\gamma$ is above 0.4 . Another complication is potentially present because one cannot exclude that the room temperature laboratory data for the ${ }^{13} \mathrm{C} \mathrm{KIE}$ for $\mathrm{CO}+\mathrm{OH}$ reaction are not applicable to the bulk of the troposphere, even though the reaction itself is little temperature- but mostly pressure-dependent (see Gromov, 2013, Sect. 6.1.4). The unbalanced ${ }^{13} \mathrm{C}(\mathrm{CO})$ budget may then be the consequence of underestimating the $\mathrm{CO}$ sink KIE in the models, despite adequate estimates of the sources' ${ }^{13} \mathrm{C} /{ }^{12} \mathrm{C}$ ratios.

\section{Conclusions}

We emphasise the value of long-term observations of $\mathrm{CO}$ isotopic composition, especially at locations like Scott Base (Antarctica), where influence of local sources is smallest and the fraction of photochemically produced $\mathrm{CO}$ is largest. In combination with modelling (e.g. EMAC), $\delta^{13} \mathrm{C}(\mathrm{CO})$ allows monitoring for intra-annual changes in the carbon isotopic composition of $\mathrm{CH}_{4}$-derived $\mathrm{CO}$, namely the $\delta^{13} \mathrm{C}$ value of reacted $\mathrm{CH}_{4}$ modified by the total sink $\operatorname{KIE}\left(\varepsilon_{\mathrm{m}}\right)$. Within the range of probable $\lambda$ values $(0.7-0.93)$, we are able to cap the potential changes in $\varepsilon_{\mathrm{m}}$ by $+(2.0-1.5) \%$ o between 1994 1996 and 1998-2000 in the ETSH, which contrasts the +8\%o derived by Allan et al. (2007). Conversely, $\delta^{13} \mathrm{C}(\mathrm{CO})$ may also be employed for "top-down" estimates of $\delta^{13} \mathrm{C}$ values of $\mathrm{CH}_{4}$ sources, provided the $\varepsilon_{\mathrm{m}}$ is equilibrated on a scale of a tropospheric $\mathrm{CH}_{4}$ lifetime. This could be achieved in a differential mixing model (also known as the "Keeling" plot) contrasting small variance in $\mathrm{CH}_{4}$-derived $[\mathrm{CO}]$ and $\delta^{13} \mathrm{C}$ and largely varying input from other $\mathrm{CO}$ sources (e.g. biomass burning).

We conclude that $\delta^{13} \mathrm{C}(\mathrm{CO})$ is particularly sensitive to the $\mathrm{CH}_{4}+\mathrm{Cl}$ sink. Its temporal variations, if they exist, may allow an independent "bottom-up" $[\mathrm{Cl}]$ proxy to be calibrated, e.g. emissions of $\mathrm{Cl}$ simulated in process-based models. For example, changes in observed $\delta^{13} \mathrm{C}(\mathrm{CO})$ at $\mathrm{SCB}$ (see Table 1) allow variations of the $\mathrm{Cl}$-driven sink of $\mathrm{CH}_{4}$ not larger than $\left(1.5 \lambda_{\mathrm{a}}^{-1}\right) \%$ of its total (assuming the yield $\lambda_{\mathrm{a}}$ of $\mathrm{CO}$ from $\mathrm{CH}_{4}$ ). Projecting this figure onto EMAC results (Table S1, zonal tropospheric integrals) implies that variations in mean ETSH chlorine abundance should have not exceeded $\Delta[\mathrm{Cl}]=\left(0.9 \lambda_{\mathrm{a}}^{-1}\right) \times 10^{3}$ atoms $\mathrm{cm}^{-3}$ between 1994 1996 and 1998-2000. Regarding the fact that Manning et al. (1997) and Bergamaschi et al. (2000) could only close the $\mathrm{SH}{ }^{13} \mathrm{C}(\mathrm{CO})$ budget assuming $\lambda$ values of 0.7 and 0.86 , which are within the generally accepted range, it is unlikely that tropospheric $\mathrm{Cl}$ is as high as assumed in the literature.

Although invoking isotopic information is often like opening a can of worms (scientists' favourite diet), relevant conclusions emerge. Lassey et al. (2011) exposed shortcomings of the phase diagram method; we show here, using a lowand high- $\mathrm{Cl}$ scenario, that unrealistic yield values of $\mathrm{CO}$ from $\mathrm{CH}_{4}$ oxidation ( $\lambda$ below 0.12 in the $\mathrm{SH}$ ) and/or implausible increases in the $\delta^{13} \mathrm{C}$ of non- $\mathrm{CH}_{4}$ sources of $\mathrm{CO}$ (exceeding $+7 \%$ at realistic $\lambda \geq 0.7$ ) would have to be assumed to explain the absence of concurrent inter-annual variations in $\delta^{13} \mathrm{C}(\mathrm{CO})$ in the ETSH. This constitutes an independent, observation-based evaluation of $[\mathrm{Cl}]$ variations envisaged by Allan et al. (2007), from which we conclude that such variations are extremely unlikely. Concerning estimates of background levels of $\mathrm{Cl}$, even attributing $1 \%$ of the total tropospheric sink of $\mathrm{CH}_{4}$ to $\mathrm{Cl}$ aggravates the non-trivial problem of balancing the global ${ }^{13} \mathrm{C}(\mathrm{CO})$ budget. It follows that the role of tropospheric $\mathrm{Cl}$ as a sink of $\mathrm{CH}_{4}$ oxidation (see, for example, Saunois et al., 2016, and references therein) is seriously overestimated.

Code availability. The Modular Earth Submodel System (MESSy) is continuously further developed and applied by a consortium of institutions. The usage of MESSy (including the EMAC model) and access to the source code is licensed to all affiliates of institutions which are members of the MESSy Consortium. Institutions can become a member of the MESSy Consortium by signing the MESSy Memorandum of Understanding. Visit the MESSy Consortium website (http://www.messy-interface.org, last access: 27 September 2017) for more information. 


\section{Appendix A: Derivations}

Below we detail the derivation of Eqs. (2) and (3). The former is obtained by writing Eq. (1) for the HC and LC periods.

${ }^{\mathrm{HC}} \delta_{\mathrm{c}}\left(1-{ }^{\mathrm{HC}} \gamma\right) \delta_{\mathrm{n}}+{ }^{\mathrm{HC}} \gamma\left(\delta_{\mathrm{m}}-{ }^{\mathrm{HC}} \varepsilon_{\mathrm{m}}\right)+\eta_{\mathrm{c}}$,

${ }^{\mathrm{LC}} \delta_{\mathrm{c}}\left(1-{ }^{\mathrm{LC}} \gamma\right) \delta_{\mathrm{n}}+{ }^{\mathrm{LC}} \gamma\left(\delta_{\mathrm{m}}-{ }^{\mathrm{LC}} \varepsilon_{\mathrm{m}}\right)+\eta_{\mathrm{c}}$,

and subtracting these to yield the respective change to $\delta_{\mathrm{c}}$ :

${ }^{\mathrm{HC}} \delta_{\mathrm{c}}-{ }^{\mathrm{LC}} \delta_{\mathrm{c}}=\left({ }^{\mathrm{HC}} \gamma-{ }^{\mathrm{LC}} \gamma\right)\left(\delta_{\mathrm{m}}-\delta_{\mathrm{n}}\right)-{ }^{\mathrm{HC}} \gamma{ }^{\mathrm{HC}} \varepsilon_{\mathrm{m}}+{ }^{\mathrm{LC}} \gamma^{\mathrm{LC}} \varepsilon_{\mathrm{m}}$.

Note that $\gamma$ is proportional to the product $(\lambda \cdot S)$ and hence increases by $\left(1+\Delta S /{ }^{\mathrm{LC}} S\right)$ during the HC period. Thus, using

$\mu=\Delta S /{ }^{\mathrm{LC}} S$,

${ }^{\mathrm{HC}} \gamma /{ }^{\mathrm{LC}} \gamma=(1+\mu)$,

$\Delta \varepsilon_{\mathrm{m}}={ }^{\mathrm{HC}} \varepsilon_{\mathrm{m}}-{ }^{\mathrm{LC}} \varepsilon_{\mathrm{m}}$,

and factoring with respect to ${ }^{\mathrm{LC}} \gamma$, one obtains:

$\Delta \delta_{\mathrm{c}} \equiv{ }^{\mathrm{HC}} \delta_{\mathrm{c}}-{ }^{\mathrm{LC}} \delta_{\mathrm{c}}={ }^{\mathrm{LC}} \gamma\left(\left(\delta_{\mathrm{m}}-{ }^{\mathrm{HC}} \varepsilon_{\mathrm{m}}-\delta_{\mathrm{n}}\right) \mu-\Delta \varepsilon_{\mathrm{m}}\right)$.

Finally, the value of $\Delta \delta_{\mathrm{c}}$ can be projected for any arbitrary yield value $\lambda_{\mathrm{a}}$ (different to $\lambda$ obtained in EMAC and used in our calculations) by scaling the value of ${ }^{\mathrm{LC}} \gamma$ with $\lambda_{\mathrm{a}} / \lambda$, which yields Eq. (2).

Derivation of Eq. (3) is done in a similar fashion, i.e. equating the right-hand sides of Eq. (1) written for $\mathrm{HC}$ and LC periods (assuming that $\delta_{\mathrm{c}}$ does not change):

$$
\begin{aligned}
& \left(1-{ }^{\mathrm{LC}} \gamma\right) \delta_{\mathrm{n}}+{ }^{\mathrm{LC}} \gamma\left(\delta_{\mathrm{m}}-{ }^{\mathrm{LC}} \varepsilon_{\mathrm{m}}\right)= \\
& \quad=\left(1-{ }^{\mathrm{LC}} \gamma(1+\mu)\right)\left(\delta_{\mathrm{n}}+\Delta \delta_{\mathrm{n}}\right) \\
& \quad+{ }^{\mathrm{LC}} \gamma(1+\mu)\left(\delta_{\mathrm{m}}-\left({ }^{\mathrm{LC}} \varepsilon_{\mathrm{m}}+\Delta \varepsilon_{\mathrm{m}}\right)\right) .
\end{aligned}
$$

Rearranging the above expression for $\Delta \delta_{\mathrm{n}}$ (required change in $\delta_{\mathrm{n}}$ sought) and factoring with respect to ${ }^{\mathrm{LC}} \gamma$ yields the following:

$\Delta \delta_{\mathrm{n}}=\frac{\left(\delta_{\mathrm{n}}-\left(\delta_{\mathrm{m}}-{ }^{\mathrm{LC}} \varepsilon_{\mathrm{m}}\right)\right) \mu+(1+\mu) \Delta \varepsilon_{\mathrm{m}}}{\left({ }^{\mathrm{LC}} \gamma\right)^{-1}-(1+\mu)}$,

where ${ }^{\mathrm{LC}} \gamma$ can be further modulated by $\lambda_{\mathrm{a}} / \lambda$ to account for an arbitrary yield value, as shown in Eq. (3). 
Supplement. The supplement related to this article is available online at: https://doi.org/10.5194/acp-18-9831-2018-supplement.

Competing interests. The authors declare that they have no conflict of interest.

Acknowledgements. We are indebted to Martin Manning and the anonymous referee whose expertise and valuable input led to significant improvement of this paper. We thank Taku Umezawa, Sander Houweling and Martin Heimann for discussions on the isotopic composition of $\mathrm{CH}_{4}$. The unique long-term trace gas records from Baring Head (New Zealand) and Scott Base (Antarctica) made available by National Institute of Water and Atmospheric Research (NIWA, 2010) are of great value. We also thank Roland Eichinger for useful comments during the paper preparation.

This work was supported by German Federal Ministry of Education and Research (BMBF) as a Research for Sustainability initiative (FONA, http://www.fona.de, last access: 16 March 2018) through the PalMod project (FKZ: 01LP1507A).

The article processing charges for this open-access publication were covered by the Max Planck Society.

Edited by: Martin Heimann

Reviewed by: Martin Manning and one anonymous referee

\section{References}

Allan, W., Manning, M. R., Lassey, K. R., Lowe, D. C., and Gomez, A. J.: Modeling the variation of $\delta^{13} \mathrm{C}$ in atmospheric methane: Phase ellipses and the kinetic isotope effect, Global Biogeochem. Cy., 15, 467-481, https://doi.org/10.1029/2000gb001282, 2001.

Allan, W., Struthers, H., and Lowe, D. C.: Methane carbon isotope effects caused by atomic chlorine in the marine boundary layer: Global model results compared with Southern Hemisphere measurements, J. Geophys. Res.-Atmos., 112, D04306, https://doi.org/10.1029/2006jd007369, 2007.

Baker, A. K., Rauthe-Schöch, A., Schuck, T. J., Brenninkmeijer, C. A. M., van Velthoven, P. F. J., Wisher, A., and Oram, D. E.: Investigation of chlorine radical chemistry in the Eyjafjallajökull volcanic plume using observed depletions in non-methane hydrocarbons, Geophys. Res. Lett., 38, L13801, https://doi.org/10.1029/2011GL047571, 2011.

Baker, A. K., Sauvage, C., Thorenz, U. R., van Velthoven, P., Oram, D. E., Zahn, A., Brenninkmeijer, C. A. M., and Williams, J.: Evidence for strong, widespread chlorine radical chemistry associated with pollution outflow from continental Asia, Sci. Rep., 6, 36821, https://doi.org/10.1038/srep36821, 2016.

Bergamaschi, P., Hein, R., Brenninkmeijer, C. A. M., and Crutzen, P. J.: Inverse modeling of the global $\mathrm{CO}$ cycle 2. Inversion of ${ }^{13} \mathrm{C} /{ }^{12} \mathrm{C}$ and ${ }^{18} \mathrm{O} /{ }^{16} \mathrm{O}$ isotope ratios, J. Geophys. Res.Atmos., 105, 1929-1945, https://doi.org/10.1029/1999jd900819, 2000

Brenninkmeijer, C. A. M.: Measurement of the abundance of ${ }^{14} \mathrm{CO}$ in the atmosphere and the ${ }^{13} \mathrm{C} /{ }^{12} \mathrm{C}$ and ${ }^{18} \mathrm{O} /{ }^{16} \mathrm{O}$ ratio of atmospheric $\mathrm{CO}$ with applications in New Zealand and Antarctica, J. Geophys. Res.-Atmos., 98, 10595-10614, https://doi.org/10.1029/93JD00587, 1993.

Brenninkmeijer, C. A. M., Müller, R., Crutzen, P. J., Lowe, D. C., Manning, M. R., Sparks, R. J., and van Velthoven, P. F. J.: A large ${ }^{13} \mathrm{CO}$ deficit in the lower Antarctic stratosphere due to "Ozone Hole" Chemistry: Part I, Observations, Geophys. Res. Lett., 23, 2125-2128, https://doi.org/10.1029/96gl01471, 1996.

Craig, H.: Isotopic standards for carbon and oxygen and correction factors for mass-spectrometric analysis of carbon dioxide, Geochim. Cosmochim. Ac., 12, 133-149, https://doi.org/10.1016/0016-7037(57)90024-8, 1957.

Crowley, J. N., Saueressig, G., Bergamaschi, P., Fischer, H., and Harris, G. W.: Carbon kinetic isotope effect in the reaction $\mathrm{CH}_{4}+\mathrm{Cl}$ : a relative rate study using FTIR spectroscopy, Chem. Phys. Lett., 303, 268-274, https://doi.org/10.1016/S00092614(99)00243-2, 1999.

Duncan, B. N., Logan, J. A., Bey, I., Megretskaia, I. A., Yantosca, R. M., Novelli, P. C., Jones, N. B., and Rinsland, C. P. Global budget of CO, 1988-1997: Source estimates and validation with a global model, J. Geophys. Res.-Atmos., 112, D22301, https://doi.org/10.1029/2007jd008459, 2007.

Emmons, L. K., Walters, S., Hess, P. G., Lamarque, J.-F., Pfister, G. G., Fillmore, D., Granier, C., Guenther, A., Kinnison, D., Laepple, T., Orlando, J., Tie, X., Tyndall, G., Wiedinmyer, C., Baughcum, S. L., and Kloster, S.: Description and evaluation of the Model for Ozone and Related chemical Tracers, version 4 (MOZART-4), Geosci. Model Dev., 3, 43-67, https://doi.org/10.5194/gmd-3-43-2010, 2010.

Folberth, G. A., Hauglustaine, D. A., Lathière, J., and Brocheton, F.: Interactive chemistry in the Laboratoire de Météorologie Dynamique general circulation model: model description and impact analysis of biogenic hydrocarbons on tropospheric chemistry, Atmos. Chem. Phys., 6, 2273-2319, https://doi.org/10.5194/acp-6-2273-2006, 2006.

Franco, B., Taraborrelli, D., Gromov, S., Pozzer, A., Clarisse, L., Coheur, P.-F., Mahieu, E., Lumenstock, T., Clerbaux, C., De Mazière, M., De Smedt, I., Griffith, D. W. T., Hannigan, J. W., Hase, F., Jones, N., Lutsch, E., Ortega, I., Paton-Walsh, C., Pommier, M., Sander, R., Schneider, M., Strong, K., Van Roozendael, M., Vigouroux, C., Kiendler-Scharr, A., and Wahner, A.: Ubiquitous production of organic acids mediated by warm clouds, in review, 2018.

Gromov, S., Jöckel, P., Sander, R., and Brenninkmeijer, C. A. M.: A kinetic chemistry tagging technique and its application to modelling the stable isotopic composition of atmospheric trace gases, Geosci. Model Dev., 3, 337-364, https://doi.org/10.5194/gmd-3337-2010, 2010.

Gromov, S., Brenninkmeijer, C. A. M., and Jöckel, P.: Uncertainties of fluxes and ${ }^{13} \mathrm{C} /{ }^{12} \mathrm{C}$ ratios of atmospheric reactive-gas emissions, Atmos. Chem. Phys., 17, 8525-8552, https://doi.org/10.5194/acp-17-8525-2017, 2017.

Gromov, S. S.: Stable isotope composition of atmospheric carbon monoxide: A modelling study, Johannes GutenbergUniversität, Mainz, urn:urn:nbn:de:hebis:77-37475, available at: http://nbn-resolving.de/urn:nbn:de:hebis:77-37475, 2013.

Hewitt, A. D., Brahan, K. M., Boone, G. D., and Hewitt, S. A.: Kinetics and mechanism of the $\mathrm{Cl}+\mathrm{CO}$ reaction in air, Int. J. Chem. Kinet., 28, 763-771, https://doi.org/10.1002/(SICI)10974601(1996)28:10<763::AID-KIN7>3.0.CO;2-L, 1996. 
Hooghiemstra, P. B., Krol, M. C., Meirink, J. F., Bergamaschi, P., van der Werf, G. R., Novelli, P. C., Aben, I., and Röckmann, T.: Optimizing global $\mathrm{CO}$ emission estimates using a four-dimensional variational data assimilation system and surface network observations, Atmos. Chem. Phys., 11, 4705-4723, https://doi.org/10.5194/acp-11-4705-2011, 2011.

Hossaini, R., Chipperfield, M. P., Saiz-Lopez, A., Fernandez, R., Monks, S., Feng, W., Brauer, P., and von Glasow, R.: A global model of tropospheric chlorine chemistry: Organic versus inorganic sources and impact on methane oxidation, J. Geophys. Res.-Atmos., 121, 271-214, 297, https://doi.org/10.1002/2016JD025756, 2016.

Jobson, B. T., Niki, H., Yokouchi, Y., Bottenheim, J., Hopper, F., and Leaitch, R.: Measurements of $\mathrm{C}_{2}-\mathrm{C}_{6}$ hydrocarbons during the Polar Sunrise1992 Experiment: Evidence for $\mathrm{Cl}$ atom and Br atom chemistry, J. Geophys. Res.-Atmos., 99, 25355-25368, https://doi.org/10.1029/94JD01243, 1994.

Jöckel, P., Kerkweg, A., Pozzer, A., Sander, R., Tost, H., Riede, H., Baumgaertner, A., Gromov, S., and Kern, B.: Development cycle 2 of the Modular Earth Submodel System (MESSy2), Geosci. Model Dev., 3, 717-752, https://doi.org/10.5194/gmd-3717-2010, 2010.

Lassey, K. R., Brailsford, G. W., Bromley, A. M., Martin, R. J., Moss, R. C., Gomez, A. J., Sherlock, V., Allan, W., Nichol, S. E., Schaefer, H., Connor, B. J., Robinson, J., and Smale, D.: Recent changes in methane mixing ratio and its ${ }^{13} \mathrm{C}$ content observed in the southwest Pacific region, J. Integr. Environ. Sci., 7, 109-117, https://doi.org/10.1080/19438151003621441, 2010.

Lassey, K. R., Allan, W., and Fletcher, S. E. M.: Seasonal interrelationships in atmospheric methane and companion $\delta^{13} \mathrm{C}$ values: effects of sinks and sources, Tellus B, 63, 287-301, https://doi.org/10.1111/j.1600-0889.2011.00535.x, 2011.

Lelieveld, J. and Crutzen, P. J.: The Role of Clouds in Tropospheric Photochemistry, J. Atmos. Chem., 12, 229-267, https://doi.org/10.1007/BF00048075, 1991.

Lelieveld, J., Gromov, S., Pozzer, A., and Taraborrelli, D.: Global tropospheric hydroxyl distribution, budget and reactivity, Atmos. Chem. Phys., 16, 12477-12493, https://doi.org/10.5194/acp-1612477-2016, 2016.

Levine, J. G., Wolff, E. W., Jones, A. E., and Sime, L. C.: The role of atomic chlorine in glacial-interglacial changes in the carbon13 content of atmospheric methane, Geophys. Res. Lett., 38, L04801, https://doi.org/10.1029/2010GL046122, 2011a.

Levine, J. G., Wolff, E. W., Jones, A. E., Sime, L. C., Valdes, P. J., Archibald, A. T., Carver, G. D., Warwick, N. J., and Pyle, J. A.: Reconciling the changes in atmospheric methane sources and sinks between the Last Glacial Maximum and the pre-industrial era, Geophys. Res. Lett., 38, L23804, https://doi.org/10.1029/2011GL049545, 2011b.

Liao, J., Huey, L. G., Liu, Z., Tanner, D. J., Cantrell, C. A., Orlando, J. J., Flocke, F. M., Shepson, P. B., Weinheimer, A. J., Hall, S. R., Ullmann, K., Beine, H. J., Wang, Y., Ingall, E. D., Stephens, C. R., Hornbrook, R. S., Apel, E. C., Riemer, D., Fried, A., Mauldin Iii, R. L., Smith, J. N., Staebler, R. M., Neuman, J. A., and Nowak, J. B.: High levels of molecular chlorine in the Arctic atmosphere, Nat. Geosci., 7 , 91-94, https://doi.org/10.1038/ngeo2046, 2014.

Logan, J. A., Prather, M. J., Wofsy, S. C., and McElroy, M. B.: Tropospheric chemistry: A global per- spective, J. Geophys. Res.-Oceans, 86, 7210-7254, https://doi.org/10.1029/JC086iC08p07210, 1981.

Lowe, D. C., Brenninkmeijer, C. A. M., Tyler, S. C., and Dlugkencky, E. J.: Determination of the isotopic composition of atmospheric methane and its application in the Antarctic, J. Geophys. Res.-Atmos., 96, 15455-15467, https://doi.org/10.1029/91JD01119, 1991.

Lowe, D. C., Allan, W., Manning, M. R., Bromley, T., Brailsford, G., Ferretti, D., Gomez, A., Knobben, R., Martin, R., Mei, Z., Moss, R., Koshy, K., and Maata, M.: Shipboard determinations of the distribution of ${ }^{13} \mathrm{C}$ in atmospheric methane in the Pacific, J. Geophys. Res.-Atmos., 104, 26125-26135, https://doi.org/10.1029/1999jd900452, 1999.

Manning, M. R., Brenninkmeijer, C. A. M., and Allan, W.: Atmospheric carbon monoxide budget of the southern hemisphere: Implications of ${ }^{13} \mathrm{C} /{ }^{12} \mathrm{C}$ measurements, J. Geophys. Res.-Atmos., 102, 10673-10682, https://doi.org/10.1029/96JD02743, 1997.

Müller, R., Brenninkmeijer, C. A. M., and Crutzen, P. J.: A Large ${ }^{13} \mathrm{CO}$ deficit in the lower Antarctic stratosphere due to "ozone hole" chemistry: Part II, Modeling, Geophys. Res. Lett., 23, 2129-2132, https://doi.org/10.1029/96g101472, 1996.

Natrella, M.: NIST/SEMATECH e-Handbook of Statistical Methods, edited by: Croarkin, C. and Tobias, P., NIST/SEMATECH, available at: http://www.itl.nist.gov/div898/handbook/ (last access: 20 August 2015), 2003.

Nisbet, E. G., Dlugokencky, E. J., Manning, M. R., Lowry, D., Fisher, R. E., France, J. L., Michel, S. E., Miller, J. B., White, J. W. C., Vaughn, B., Bousquet, P., Pyle, J. A., Warwick, N. J., Cain, M., Brownlow, R., Zazzeri, G., Lanoisellé, M., Manning, A. C., Gloor, E., Worthy, D. E. J., Brunke, E. G., Labuschagne, C., Wolff, E. W., and Ganesan, A. L.: Rising atmospheric methane: 2007-2014 growth and isotopic shift, Global Biogeochem. Cy., 30, 1356-1370, https://doi.org/10.1002/2016GB005406, 2016.

NIWA: Publicly available data on from several greenhouse gas measurement projects (TROPAC), National Institute of Water and Atmospheric Research, New Zealand, available at: ftp://ftp.niwa. co.nz/tropac/ (last access: 23 June 2016), 2010.

Osthoff, H. D., Roberts, J. M., Ravishankara, A. R., Williams, E. J., Lerner, B. M., Sommariva, R., Bates, T. S., Coffman, D., Quinn, P. K., Dibb, J. E., Stark, H., Burkholder, J. B., Talukdar, R. K., Meagher, J., Fehsenfeld, F. C., and Brown, S. S.: High levels of nitryl chloride in the polluted subtropical marine boundary layer, Nat. Geosci., 1, 324-328, https://doi.org/10.1038/ngeo177, 2008.

Parrish, D. D., Hahn, C. J., Williams, E. J., Norton, R. B., Fehsenfeld, F. C., Singh, H. B., Shetter, J. D., Gandrud, B. W., and Ridley, B. A.: Reply [to Comment on "Indications of photochemical histories of Pacific air masses from measurements of atmospheric trace species at Point Arena, California' by D. D. Parrish et al.”], J. Geophys. Res.-Atmos., 98, 14995-14997, https://doi.org/10.1029/93JD01416, 1993.

Platt, U., Allan, W., and Lowe, D.: Hemispheric average $\mathrm{Cl}$ atom concentration from ${ }^{13} \mathrm{C} /{ }^{12} \mathrm{C}$ ratios in atmospheric methane, Atmos. Chem. Phys., 4, 2393-2399, https://doi.org/10.5194/acp-42393-2004, 2004.

Röckmann, T., Brenninkmeijer, C. A. M., Crutzen, P. J., and Platt, U.: Short-term variations in the ${ }^{13} \mathrm{C} /{ }^{12} \mathrm{C}$ ratio of $\mathrm{CO}$ as a measure of $\mathrm{Cl}$ activation during tropospheric ozone depletion 
events in the Arctic, J. Geophys. Res.-Atmos., 104, 1691-1697, https://doi.org/10.1029/1998JD100020, 1999.

Sander, R., Baumgaertner, A., Gromov, S., Harder, H., Jöckel, P., Kerkweg, A., Kubistin, D., Regelin, E., Riede, H., Sandu, A., Taraborrelli, D., Tost, H., and Xie, Z.-Q.: The atmospheric chemistry box model CAABA/MECCA-3.0, Geosci. Model Dev., 4, 373-380, https://doi.org/10.5194/gmd-4-373-2011, $2011 \mathrm{a}$.

Sander, S. P., Friedl, R. R., Abbatt, J. P. D., Barker, J. R., Burkholder, J. B., Golden, D. M., Kolb, C. E., Kurylo, M. J., Moortgat, G. K., Wine, P. H., Huie, R. E., and Orkin, V. L.: Chemical Kinetics and Photochemical Data for Use in Atmospheric Studies, Evaluation No. 17(JPL Publication 10-6), NASA Jet Propulsion Laboratory, Pasadena, CA, 2011b.

Saueressig, G., Bergamaschi, P., Crowley, J. N., Fischer, H., and Harris, G. W.: Carbon kinetic isotope effect in the reaction of $\mathrm{CH}_{4}$ with $\mathrm{Cl}$ atoms, Geophys. Res. Lett., 22, 1225-1228, https://doi.org/10.1029/95GL00881, 1995.

Saueressig, G., Crowley, J. N., Bergamaschi, P., Brühl, C., Brenninkmeijer, C. A. M., and Fischer, H.: Carbon 13 and $\mathrm{D}$ kinetic isotope effects in the reactions of $\mathrm{CH}_{4}$ with $\mathrm{O}\left({ }^{1} \mathrm{D}\right)$ and $\mathrm{OH}$ : New laboratory measurements and their implications for the isotopic composition of stratospheric methane, J. Geophys. Res.-Atmos., 106, 23127-23138, https://doi.org/10.1029/2000jd000120, 2001.

Saunois, M., Bousquet, P., Poulter, B., Peregon, A., Ciais, P., Canadell, J. G., Dlugokencky, E. J., Etiope, G., Bastviken, D., Houweling, S., Janssens-Maenhout, G., Tubiello, F. N., Castaldi, S., Jackson, R. B., Alexe, M., Arora, V. K., Beerling, D. J., Bergamaschi, P., Blake, D. R., Brailsford, G., Brovkin, V., Bruhwiler, L., Crevoisier, C., Crill, P., Covey, K., Curry, C., Frankenberg, C., Gedney, N., Höglund-Isaksson, L., Ishizawa, M., Ito, A., Joos, F., Kim, H.-S., Kleinen, T., Krummel, P., Lamarque, J.-F., Langenfelds, R., Locatelli, R., Machida, T., Maksyutov, S., McDonald, K. C., Marshall, J., Melton, J. R., Morino, I., Naik, V., O’Doherty, S., Parmentier, F.-J. W., Patra, P. K., Peng, C., Peng, S., Peters, G. P., Pison, I., Prigent, C., Prinn, R., Ramonet, M., Riley, W. J., Saito, M., Santini, M., Schroeder, R., Simpson, I. J., Spahni, R., Steele, P., Takizawa, A., Thornton, B. F., Tian, H., Tohjima, Y., Viovy, N., Voulgarakis, A., van Weele, M., van der Werf, G. R., Weiss, R., Wiedinmyer, C., Wilton, D. J., Wiltshire, A., Worthy, D., Wunch, D., Xu, X., Yoshida, Y., Zhang, B., Zhang, Z., and Zhu, Q.: The global methane budget 2000-2012, Earth Syst. Sci. Data, 8, 697-751, https://doi.org/10.5194/essd-8-697-2016, 2016.
Schaefer, H., Fletcher, S. E. M., Veidt, C., Lassey, K. R., Brailsford, G. W., Bromley, T. M., Dlugokencky, E. J., Michel, S. E., Miller, J. B., Levin, I., Lowe, D. C., Martin, R. J., Vaughn, B. H., and White, J. W. C.: A 21st century shift from fossil-fuel to biogenic methane emissions indicated by ${ }^{13} \mathrm{CH}_{4}$, Science, 352 , 80-84, https://doi.org/10.1126/science.aad2705, 2016.

Spicer, C. W., Chapman, E. G., Finlayson-Pitts, B. J., Plastridge, R. A., Hubbe, J. M., Fast, J. D., and Berkowitz, C. M.: Unexpectedly high concentrations of molecular chlorine in coastal air, Nature, 394, 353-356, https://doi.org/10.1038/28584, 1998.

Thornton, J. A., Kercher, J. P., Riedel, T. P., Wagner, N. L., Cozic, J., Holloway, J. S., Dubé, W. P., Wolfe, G. M., Quinn, P. K., Middlebrook, A. M., Alexander, B., and Brown, S. S.: A large atomic chlorine source inferred from midcontinental reactive nitrogen chemistry, Nature, 464, 271-274, https://doi.org/10.1038/nature08905, 2010.

Tie, X., Jim Kao, C. Y., and Mroz, E. J.: Net yield of OH, CO, and $\mathrm{O}_{3}$ from the oxidation of atmospheric methane, Atmos. Environ. A-Gen., 26, 125-136, https://doi.org/10.1016/09601686(92)90265-M, 1992.

Turner, A. J., Frankenberg, C., Wennberg, P. O., and Jacob, D. $\mathrm{J}$.: Ambiguity in the causes for decadal trends in atmospheric methane and hydroxyl, P. Natl. Acad. Sci. USA, 114, 5367-5372, https://doi.org/10.1073/pnas.1616020114, 2017.

Whitehill, A. R., Joelsson, L. M. T., Schmidt, J. A., Wang, D. T., Johnson, M. S., and Ono, S.: Clumped isotope effects during $\mathrm{OH}$ and $\mathrm{Cl}$ oxidation of methane, Geochim. Cosmochim. Ac., 196, 307-325, https://doi.org/10.1016/j.gca.2016.09.012, 2017.

Young, C. J., Washenfelder, R. A., Roberts, J. M., Mielke, L. H., Osthoff, H. D., Tsai, C., Pikelnaya, O., Stutz, J., Veres, P. R., Cochran, A. K., VandenBoer, T. C., Flynn, J., Grossberg, N., Haman, C. L., Lefer, B., Stark, H., Graus, M., de Gouw, J., Gilman, J. B., Kuster, W. C., and Brown, S. S.: Vertically Resolved Measurements of Nighttime Radical Reservoirs in Los Angeles and Their Contribution to the Urban Radical Budget, Environ. Sci. Technol., 46, 10965-10973, https://doi.org/10.1021/es302206a, 2012. 